SOUTH ASIAN ATLANTIC LITERATURE, 1970-2010 


\section{EDINBURGH STUDIES IN TRANSATLANTIC LITERATURES}

Series Editors: Susan Manning and Andrew Taylor

Modern global culture makes it clear that literary study can no longer operate on nation-based or exceptionalist models. In practice, American literatures have always been understood and defined in relation to the literatures of Europe and Asia. The books in this series work within a broad comparative framework to question place-based identities and monocular visions, in historical contexts from the earliest European settlements to contemporary affairs, and across all literary genres. They explore the multiple ways in which ideas, texts, objects and bodies travel across spatial and temporal borders, generating powerful forms of contrast and affinity. The Edinburgh Studies in Transatlantic Literatures series fosters new paradigms of exchange, circulation and transformation for transatlantic literary studies, expanding the critical and theoretical work of this rapidly developing field.

Titles in the series include:

Ethnicity and Cultural Authority: From Arnold to Du Bois, Daniel G. Williams

Henry Fames, Oscar Wilde and Aesthetic Culture, Michèle Mendelssohn American Modernism's Expatriate Scene: The Labour of Translation, Daniel Katz

The Dandy in Irish and American Southern Fiction: Aristocratic Drag, Ellen Crowell

Philanthropy in British and American Fiction: Dickens, Hawthorne, Eliot, and Howells, Frank Christianson

Transatlantic Women's Literature, Heidi Slettedahl Macpherson

Cultural Authority in the Age of Whitman: A Transatlantic Perspective, Günter Leypoldt

Mercenaries in British and American Literature, I790-I830: Writing, Fighting, and Marrying for Money, Erik Simpson

Spanish America and British Romanticism, I777-I826: Rewriting Conquest, Rebecca Cole Heinowitz

Transnationalism in Practice: Essays on American Studies, Literature and Religion, Paul Giles

South Asian Atlantic Literature, 1970-2010, Ruth Maxey

Visit the Edinburgh Studies in Transatlantic Literature web site at www. euppublishing.com/series/estl 


\title{
SOUTH ASIAN
}

ATLANTIC

LITERATURE,

I 970-20 I O

$\bullet \bullet$

\author{
RUTH MAXEY
}

EDINBURGH UNIVERSITY PRESS 
For my parents, with love and thanks

(C) Ruth Maxey, 2012

Edinburgh University Press Ltd

22 George Square, Edinburgh

www.euppublishing.com

Typeset in II/I3 Baskerville MT

by Servis Filmsetting Ltd, Stockport, Cheshire, and printed and bound in Great Britain by

CPI Group (UK) Ltd, Croydon CR0 4YY

A CIP record for this book is available from the British Library

ISBN 9780748641888 (hardback)

The right of Ruth Maxey

to be identified as author of this work

has been asserted in accordance with

the Copyright, Designs and Patents Act 1988. 